\title{
HUBUNGAN JUMLAH INSERSI DENGAN KEJADIAN PHLEBITIS PADA PASIEN ANAK DI RUMAH SAKIT UMUM DAERAH KOTA KENDARI
}

\author{
Dina Mariana $\mathrm{L}^{1}$, Muhammad Asrul ${ }^{2}$ \\ ${ }^{1}$ Dosen Program Sarjana Ilmu Keperawatan Universitas Sam Ratulangi \\ ${ }^{2}$ Kepala Bagian Pusat Pengendalian Infeksi (PPI) Rumah Sakit Umum Daerah Kota Kendari \\ Email: dinamariana@unsrat.ac.id
}

\begin{abstract}
Abstrac: One indicator of the quality of health services and a serious problem for all hospitals is nosocomial infection. Nosocomial infection is the presence of an infection that is acquired or experienced by the patient during his hospitalization and shows symptoms of a new infection after 72 hours the patient is in the hospital. One of the nosocomial infections that often appears in the hospital is phlebitis. This study aims to determine the relationship of the total of insertions with phlebitis events in pediatric patients at General Regional Hospital in Kendari 2018.

This research is a descriptive analytic study with a cross sectional study approach. The population in this study were pediatric patients in the Mawar treatment room, amounting to 175 people at General Regional Hospital in Kendari. The sample consisted of 35 respondents, the sampling technique was purposive sampling. The statistical test used was the Fisher Exact Test and Mann Whitney test. The results showed that there was a correlation between the number of insertions and phlebitis events in pediatric patients in Kendari City Hospital which was indicated by the value of $\rho$ value $=0,000$. It was concluded that there was a relationship between the amount of insertion with phlebitis events in pediatric patients at General Regional Hospital in Kendari. It is recommended that this study be continued by using more samples and using research methods with the type of case control.
\end{abstract}

Keywords : total insertion, phlebitis incidence

Abstrak: Salah satu indikator mutu pelayanan kesehatan dan merupakan masalah serius bagi semua rumah sakit adalah infeksi nosokomial. Infeksi nosokomial adalah adanya infeksi yang diperoleh atau dialami oleh pasien selama dia dirawat di rumah sakit dan menunjukkan gejala infeksi baru setelah 72 jam pasien berada di rumah sakit. Salah satu infeksi nosokomial yang sering muncul di rumah sakit adalah phlebitis. Penelitian ini bertujuan untuk mengetahui hubungan jumlah insersi dengan kejadian phlebitis pada pasien anak di RSUD Kota Kendari. Penelitian ini merupakan penelitian deskriptif analitik dengan pendekatan cross sectional study. Populasi dalam penelitian ini adalah pasien anak di ruang perawatan Mawar yang berjumlah 175 orang di RSUD Kota Kendari. Sampel berjumlah 35 responden, teknik penarikan sampel yaitu purposive sampling. Uji statistik yang digunakan adalah uji Fisher Exact Test dan uji Mann Whitney. Hasil penelitian menunjukkan ada hubungan antara jumlah insersi dengan kejadian phlebitis pada pasien anak di RSUD Kota Kendari yang ditunjukkan dengan nilai $\rho$ value $=0,000$. Disimpulkan bahwa terdapat hubungan antara jumlah insersi dengan kejadian phlebitis pada pasien anak di RSUD Kota Kendari. Disarankan penelitian ini dilanjutkan dengan menggunakan sampel yang lebih banyak dan menggunakan metode penelitian dengan jenis case control.

Kata Kunci : jumlah insersi, kejadian phlebitis 


\section{PENDAHULUAN}

Health Care Associated Infections (HAIs) dengan pengertian yang lebih luas tidak hanya di rumah sakit tetapi juga di fasilitas pelayanan kesehatan lainnya. HAIs adalah infeksi yang disebabkan oleh mikroorganisme dan bakteri yang didapat pada waktu pasien dirawat 3x24 jam di rumah sakit dimana pasien tersebut tidak menunjukkan gejala infeksi saat masuk rumah sakit. Tingginya angka infeksi HAIs menjadi masalah yang penting di suatu rumah sakit (Aisyah, 2012).

HAIs saat ini merupakan salah satu penyebab meningkatnya angka kesakitan (morbidity) dan angka kematian (mortality) di rumah sakit sehingga menjadi permasalahan baru di bidang kesehatan (Depkes, 2015).

HAIs dapat memperpanjang hari rawat pasien selama 4-5 hari dan bahkan bisa menjadi penyebab kematian pasien. Sebuah survei prevalensi dilakukan oleh WHO di 55 rumah sakit dari 14 negara yang mewakili 4 wilayah WHO (Asia Tenggara, Eropa, Mediterania Timur, dan Pasifik Barat) mengungkapkan bahwa rata-rata $8,7 \%$ pasien rumah sakit menderika infeksi HAIs (WHO, 2015).

Rumah sakit merupakan suatu kompleks yang padat, baik padat tenaga, profesi, prosedur, teknologi dan sebagainya, sehingga mudah terjadi permasalahan dalam mutu pelayanan, seperti mudahnya terjadi kejadian tidak diharapkan dalam pelayanan kesehatan rumah sakit yang dapat meningkatkan mortalitas, morbiditas dan prolonged hospital stay (Sitorus, 2012). Salah satu indikator mutu pelayanan kesehatan dan merupakan masalah serius bagi semua rumah sakit dimana kerugian yang ditimbulkan tidak hanya membebani pasien, keluarga, tenaga yang bekerja di rumah sakit, akan tetapi mempengaruhi juga citra rumah sakit di mata masyarakat sehingga akan menimbulkan kerugian terhadap rumah sakit tersebut merupakan infeksi nosokomial.
Infeksi nosokomial adalah adanya infeksi yang diperoleh atau dialami oleh pasien selama dia dirawat di rumah sakit dan menunjukkan gejala infeksi baru setelah 72 jam pasien berada di rumah sakit serta infeksi ini tidak ditemukan atau diderita pada saat pasien masuk ke rumah sakit (Darmadi, 2009). Salah satu infeksi nosokomial yang sering muncul di rumah sakit adalah phlebitis. Phlebitis merupakan reaksi inflamasi yang terjadi pada pembuluh darah vena yang ditandai dengan nyeri, kemerahan, bengkak, panas, indurasi (pengerasan) pada daerah tusukan dan pengerasan sepanjang pembuluh darah vena (Alexander, 2010). Angka kejadian phlebitis merupakan salah satu indikator dari mutu pelayanan rumah sakit yakni sebagai indikator pelayanan mutu, minimal rumah sakit dengan standar angka kejadian $\leq 1,5 \%$ (Rizky \& Supriyatiningsih, 2014).

Faktor penyebab dari phlebitis terdiri dari faktor internal dan eksternal, yang termasuk faktor penyebab internal dari phlebitis adalah usia, status gizi, stres, kondisi vena, faktor penyakit pasien rawat inap yang terpasang infus serta jenis kelamin (Perry dan Potter, 2010). Sedangkan faktor eksternal dari phlebitis terdiri dari 3 jenis yaitu: faktor kimia, faktor mekanik dan faktor bakterial (Alexander,et al, 2011).

Salah satu yang memberi kontribusi terhadap faktor bakterial dari phlebitis adalah durasi pemasangan infus yang terlalu lama. Tujuan dari pemasangan infus yaitu untuk memperbaiki kondisi pasien dengan mempertahankan keseimbangan cairan, mengganti elektrolit tubuh dan zat makanan yang hilang dan juga sebagai media pemberian obat dan vitamin. Pemasangan infus yang diberikan secara terus-menerus dan dalam jangka waktu lama akan meningkatkan kemungkinan terjadinya komplikasi dari pemasangan infus, salah satunya adalah phlebitis (Pradini, 2016).

Penelitian yang dilakukan oleh Christian Komaling, dkk (2014) diketahui bahwa dari total 21 responden yang lama 
pemasangan infus lebih dari 72 jam $(\geq 3$ hari), 16 responden $(27,6 \%)$ mengalami phlebitis, sedangkan 5 responden $(8,6 \%)$ tidak mengalami phlebitis. Sedangkan dari 37 responden yang dipasangi infus $48-72$ jam $(\leq 3$ hari), 4 responden $(6,9 \%)$ mengalami phlebitis, sedangkan 33 responden $(56,9 \%)$ tidak mengalami phlebitis (Komaling, 2014).

Berdasarkan data statistik yang didapatkan dari Yayasan Kesehatan mengenai infeksi nosokomial, phlebitis menempati peringkat pertama infeksi nosokomial di Indonesia dibandingkan infeksi lainnya yaitu sebanyak 16.435 kejadian phlebitis dari 588.328 pasien berisiko di Rumah Sakit Umum Indonesia atau lebih kurang 2,8\% dan sebanyak 293 kejadian phlebitis dari 18.800 pasien yang berisiko di Rumah Sakit khusus atau swasta di Indonesia pada tahun 2007 atau kurang lebih 1,5\%. Sedangkan, data Depkes RI tahun 2013 angka kejadian phlebitis di Indonesia sebesar 50,11\% untuk Rumah Sakit Umum di Indonesia sedangkan untuk Rumah Sakit khusus atau swasta sebesar 32,70\% (Rizky \& Supriyatiningsih, 2014).

Phlebitis dapat terjadi meskipun telah dilaksanakan pengawasan yang ketat. Penelitian menunjukan bahwa banyak kasus phlebitis menampakan gejala awal lebih dari 12 jam setelah penghentian kateter. Metode pencegahan yang dapat menurunkan risiko infeksi meliputi teknik steril selama pemasangan dan perubahan tempat setiap 72 jam. Diagnosa didasarkan pada adanya demam, nyeri, eritema, indurasi dan cord yang jelas atau dapat dipalpasi. Perawatan mencakup pemindahan kateter dan kompres hangat. Dalam jurnal keperawatan Soedirman (2010), penelitian yang dilakukan oleh Asrin dan tim didapatkan hasil penelitian bahwa 74 pasien dengan 17 pasien mengalami phlebitis (22,9\%). Dari hasil penelitian tersebut didapatkan bahwa faktor yang mempengaruhi terjadinya phlebitis adalah jenis ukuran dan bahan kateter, lama waktu pemasangan, pemilihan tempat insersi, jnis penutup tempat penusukan, teknik insersi, sterilitas perawatan terapi intravena. Sedangkan menurut penelitian yang dilakukan oleh Hetti Aprilin dalam jurnal Keperawatan Volume 1 (2011), didapatkan hasil penelitian bahwa dari 20 responden 2 (10\%) tidak dilakukan perawatan infus, 6 (30\%) terjadi phlebitis.

Hal tersebut didukung oleh penelitian yang dilakukan oleh Asrin dkk di RSUD Purbalingga pada tahun 2011. Dari hasil penelitian tersebut, didapatkan bahwa jenis cairan intravena yang diberikan menjadi penyebab terjadinya phlebitis dengan nilai $p$ value $(0,01)$, golongan obat pekat dapat menyebabkan phlebitis dengan nilai $p$ value $(0,02)$, lokasi pemasangan infus sebagai salah satu faktor penyebab phlebitis dengan nilai $p$ value $(0,01)$, ukuran kanula berpengaruh dengan phlebitis dengan nilai $p$ value $(0,01)$, lama pemasangan kateter dalam terapi intravena akan mempengaruhi phlebitis dengan nilai $p$ value $(0,01)$, prosedur teknik cuci tangan akan mempengaruhi phlebitis dengan nilai $p$ value $(0,01)$, prosedur teknik aseptik akan mempengaruhi terjadinya phlebitis dengan nilai $p$ value $(0,01)$, prosedur teknik aseptik akan mempengaruhi terjadinya phlebitis dengan nilai $p$ value $(0,01)$, teknik pemasangan kanula akan mempengaruhi terjadinya phlebitis dengan nilai $p$ value $(0,01)$, perawatan infus juga berpengaruh terhadap kejadian phlebitis dengan nilai $p$ value $(0,01)$.

Berdasarkan dari data laporan surveilans yang didapatkan di Rumah Sakit Umum Daerah Kota Kendari bahwa total angka kejadian phlebitis pada bulan Januari 2018 terdapat 10 (4,02\%) kasus, bulan Februari 2018 terdapat $4(1,66 \%)$ kasus, bulan Maret 2018 terdapat $8(3,16 \%)$ kasus, dan bulan April 2018 terdapat $5(1,97 \%)$ kasus. Berdasarkan wawancara dari beberapa perawat di ruang rawat inap anak RSUD Kota Kendari didapatkan bahwa kejadian phlebitis tersebut selalu ada setiap bulannya dan petugas bagian PPI mengatakan bahwa phlebitis merupakan salah satu HAIS. 
Fenomena tersebut menggambarkan bahwa masih ditemukan angka kejadian phlebitis di ruang rawat inap anak RSUD Kota Kendari. Hal tersebut menunjukkan bahwa prevalensi kejadian phlebitis masih di bawah standar indikator mutu pelayanan. Berdasarkan hal di atas penulis tertarik untuk melakukan penelitian tentang hubungan jumlah insersi dan rotasi infus dengan kejadian phlebitis pada pasien anak di RSUD Kota Kendari.

\section{METODE PENELITIAN}

Jenis penelitian yang digunakan adalah survey deskriptif dengan pendekatan Crosssectional. Desain yang digunakan pada penelitian ini digunakan untuk mendeskripsikan dan menginterpretasikan mengenai hubungan jumlah insersi dan rotasi infus dengan kejadian phlebitis pada pasien anak di RSUD Kota Kendari. Penelitian ini telah dilaksanakan di RSUD Kota Kendari yang dilaksanakan pada tanggal 12-27 Agustus 2018.

Populasi dalam penelitian ini adalah adalah seluruh pasien anak di ruang perawatan Mawar (ruang anak) RSUD Kota Kendari pada bulan Januari s/d Maret yang berjumlah 175 anak. Teknik pengambilan sampel yang digunakan peneliti adalah purposive sampling, yaitu penelitian yang didasarkan pada suatu pertimbangan tertentu yang dibuat oleh peneliti sendiri berdasarkan ciri atau sifat-sifat populasi yang sudah diketahui sebelumnya.

Besar sampel dalam penelitian ini dengan menggunakan rumus Arikunto, 2012. Menurut Arikunto (2012), jika jumlah subyeknya lebih besar dari 100 maka dapat diambil antara 20\%-25\% dari populasi dengan rumus:

Keterangan :

$$
\mathrm{n}=20 \% \times \mathrm{N}
$$

$\mathrm{N}=$ Besar populasi

$\mathrm{n}=$ Besar sampel

Berdasarkan rumus tersebut diperoleh besar sampel sebagai berikut:

$$
\mathrm{n}=20 \% \times 175=35
$$

Jadi sampel dalam penelitian ini sebanyak 35 responden. Kriteria inklusi dalam penelitian ini adalah: Anak yang dirawat di ruang perawatan anak (Ruang Mawar) usia 1-18 tahun, anak yang sedang terpasang infus, anak yang dirawat $\geq 2$ hari, Anak yang bersedia menjadi responden. Sedangkan kriteria eksklusi dalam penelitian ini adalah: anak yang dirawat $<2$ hari, dan anak dengan kondisi gangguan kesadaran.

Instrumen yang digunakan dalam penelitian ini adalah lembar observasi yang terbagi dalam tiga bagian, yaitu jumlah insersi, rotasi infus, dan kejadian phlebitis.

\section{HASIL DAN PEMBAHASAN}

\section{a. Karakteristik Variabel}

Tabel 1. Distribusi Responden Berdasarkan Karakteristik Usia pada Pasien Anak di RSUD Kota Kendari

\begin{tabular}{lcc}
\hline Usia & n & \% \\
\hline $0-5$ & 16 & 45,7 \\
$6-11$ & 16 & 45,7 \\
$12-18$ & 3 & 8,6 \\
Jumlah & $\mathbf{3 5}$ & $\mathbf{1 0 0}$ \\
\hline
\end{tabular}

Sumber: Data primer diolah tahun 2018

Tabel 1 menggambarkan menunjukkan bahwa dari 35 responden, usia responden dengan jumlah tertinggi berada pada usia 0-11 tahun yaitu sebanyak $32 \quad(91,4 \%)$ responden, dan jumlah yang terendah berada pada usia $12-18$ tahun yaitu sebanyak $3(8,6 \%)$ responden. 


\section{b. Jenis Kelamin}

Tabel 2. Distribusi Responden Menurut Karakteristik Jenis Kelamin pada Pasien Anak di RSUD Kota Kendari

\begin{tabular}{ccc}
\hline Jenis Kelamin & $\mathrm{n}$ & $\%$ \\
\hline Laki-laki & 20 & 57,2 \\
Perempuan & 15 & 42,9 \\
\hline Jumlah & $\mathbf{3 5}$ & $\mathbf{1 0 0}$
\end{tabular}

Sumber: Data primer 2018

Tabel 2 di atas menunjukkan bahwa dari 35 responden, jenis kelamin responden dengan jumlah tertinggi berada pada jenis kelamin laki-laki yaitu sebanyak 20 responden dengan persentase sebesar $57,2 \%$, dan perempuan sebanyak 15 responden dengan persentase sebesar $42,9 \%$.

\section{c. Jumlah Insersi}

Tabel 3. Distribusi Responden Menurut Karakteristik Jumlah Insersi Pada Pasien Anak di RSUD Kota Kendari.

\begin{tabular}{ccc}
\hline $\begin{array}{c}\text { Jumlah } \\
\text { Insersi }\end{array}$ & $\mathrm{n}$ & $\%$ \\
\hline$>2$ kali & 27 & 77,1 \\
$\leq 2$ kali & 8 & 22,9 \\
\hline Jumlah & $\mathbf{3 5}$ & $\mathbf{1 0 0}$ \\
\hline
\end{tabular}

Sumber: Data primer 2018

Tabel 3 di atas menunjukkan bahwa jumlah insersi $>2$ kali yaitu sebanyak $27(77,1 \%)$ responden, sedangkan jumlah insersi $\leq 2$ kali hanya sebanyak $8(22,9 \%)$ responden.

\section{d. Phlebitis}

Tabel 4. Distribusi Responden Menurut Kejadian Phlebitis Pada Pasien Anak di RSUD Kota Kendari

\begin{tabular}{ccc}
\hline $\begin{array}{c}\text { Kejadian } \\
\text { Phlebitis }\end{array}$ & $\mathrm{n}$ & $\%$ \\
\hline Ya & 28 & 80,0 \\
Tidak & 7 & 20,0 \\
\hline Jumlah & $\mathbf{3 5}$ & $\mathbf{1 0 0}$ \\
\hline
\end{tabular}

Sumber: Data primer 2018
Tabel 4 di atas menunjukkan bahwa dari 35 responden, kejadian phlebitis pada pasien anak yakni sebanyak $28(80 \%)$ responden, sedangkan hanya 7 anak (20\%) yang tidak mengalami phlebitis.

\section{e. Analisis Bivariat}

Tabel 5. Distribusi hubungan jumlah insersi dengan kejadian phlebitis pada pasien anak di RSUD Kota Kendari

\begin{tabular}{|c|c|c|c|c|c|c|c|}
\hline \multirow{3}{*}{$\begin{array}{c}\text { Jumlah } \\
\text { insersi }\end{array}$} & \multicolumn{4}{|c|}{ Phlebitis } & & & \multirow{3}{*}{$\begin{array}{c}p \\
\text { value }\end{array}$} \\
\hline & \multicolumn{2}{|c|}{ Ya } & \multicolumn{2}{|c|}{ Tidak } & \multicolumn{2}{|c|}{ Total } & \\
\hline & $\mathbf{n}$ & $\%$ & n & $\%$ & n & $\%$ & \\
\hline$>2$ kali & 26 & 92,9 & 1 & 14,3 & 27 & 77,1 & \\
\hline$\leq 2$ kali & 2 & 7,1 & 6 & 85,7 & 8 & 22,9 & \\
\hline Total & 28 & 100 & 7 & 100 & 35 & 100 & \\
\hline
\end{tabular}

Uji Fisher exact

Hasil analisis pada tabel 5 menunjukkan bahwa jumlah insersi jarum infus yang $>2$ kali memiliki tingkat kejadian phlebitis sebanyak $26(92,9 \%)$, dan kejadian tidak phlebitis hanya sebanyak $1 \quad(14,3 \%)$ responden. Selain itu, jumlah insersi jarum infus yang $\leq 2$ kali memiliki tingkat kejadian phlebitis hanya sebanyak 2 kali $(7,1 \%)$, sedangkan tingkat kejadian tidak phlebitis sebanyak $6(85,7 \%)$ responden.

Hasil analisa dan perhitungan dengan menggunakan rumus uji Fisher exact secara komputerisasi diperoleh nilai $\rho$ value $=$ 0,000, maka Ha diterima dan Ho ditolak, dengan demikian ada hubungan yang signifikan antara jumlah insersi dengan kejadian phlebitis pada pasien anak di RSUD Kota Kendari.

Tabel 6. Distribusi hubungan jumlah insersi dengan kejadian phlebitis pada pasien anak di RSUD Kota Kendari

\begin{tabular}{|c|c|c|c|c|c|c|c|}
\hline \multirow{3}{*}{$\begin{array}{l}\text { Rotasi } \\
\text { infus }\end{array}$} & \multicolumn{4}{|c|}{ Phlebitis } & \multirow{2}{*}{\multicolumn{2}{|c|}{ Total }} & \multirow{3}{*}{$\begin{array}{c}p \\
\text { value }\end{array}$} \\
\hline & \multicolumn{2}{|c|}{ Ya } & \multicolumn{2}{|c|}{ Tidak } & & & \\
\hline & $\mathrm{n}$ & $\%$ & $\mathrm{n}$ & $\%$ & $\mathrm{n}$ & $\%$ & \\
\hline$>72$ jam & 18 & 100 & 0 & 0 & 18 & 100 & \\
\hline 48-72 jam & 7 & 50 & 7 & 50 & 14 & 100 & 0,015 \\
\hline$\leq 24 \mathrm{jam}$ & 3 & 100 & 0 & 0 & 3 & 100 & \\
\hline Total & 28 & 100 & 7 & 100 & 35 & 100 & \\
\hline
\end{tabular}


Hasil analisis pada tabel 5.8 menunjukkan bahwa jumlah rotasi infus yang $>72$ jam memiliki tingkat kejadian phlebitis sebanyak 18 (100\%), sedangkan yang tidak mengalami phlebitis sebanyak $0 \quad(0 \%)$ responden. Jumlah rotasi infus $48 \square 72 \mathrm{jam}$ yang memiliki tingkat kejadian phlebitis sebanyak $7(50 \%)$ responden, sedangkan yang tidak mengalami phlebitis juga sebanyak 7 (50\%) responden. Selain itu, jumlah rotasi infus yang $\leq 24$ jam memiliki tingkat kejadian phlebitis sebanyak 3 $(100 \%)$, sedangkan yang tidak mengalami phlebitis sebanyak $0(0 \%)$ responden.

Hasil analisa dan perhitungan dengan menggunakan rumus uji Mann Whitney secara komputerisasi diperoleh nilai $\rho$ value $=0,015$, maka Ha diterima dan Ho ditolak, dengan demikian ada hubungan yang signifikan antara rotasi infus dengan kejadian phlebitis pada pasien anak di RSUD Kota Kendari.

\section{PEMBAHASAN}

Hasil analisa dan perhitungan dengan menggunakan rumus uji Fisher exact secara komputerisasi diperoleh nilai $\rho$ value $=$ 0,000, maka Ha diterima dan $\mathrm{H}_{\mathrm{o}}$ ditolak, dengan demikian ada hubungan yang signifikan antara jumlah insersi dengan kejadian phlebitis pada pasien anak di RSUD Kota Kendari. Berdasarkan hasil analisis diperoleh bahwa jumlah insersi jarum infus yang $>2$ kali memiliki tingkat kejadian phlebitis sebanyak 26 (92,9\%), dan kejadian tidak phlebitis hanya sebanyak $1(14,3 \%)$ responden. Selain itu, jumlah insersi jarum infus yang $\leq 2$ kali memiliki tingkat kejadian phlebitis hanya sebanyak 2 kali $(7,1 \%)$, sedangkan tingkat kejadian tidak phlebitis sebanyak $6 \quad(85,7 \%)$ responden.

Perry \& Potter (2010) mengatakan bahwa kejadian phlebitis yang terjadi disebabkan karena teknik insersi intravena yang tidak dilakukan dengan benar sehingga menyebabkan perlukaan pada lokasi insersi yang dapat dijadikan sebagai port de entry bagi mikroorganisme. Adanya luka menyebabkan mikroorganisme berkembang dan menyebabkan adanya tanda-tanda phlebitis yang ditunjukkan dengan adanya bengkak pada daerah pemasangan, teraba nyeri, kemerahan dan teraba hangat.

Dari hasil penelitian ini didapatkan bahwa pasien dengan jumlah insersi $>2$ kali yaitu sebanyak $27(77,1 \%)$ responden, dimana yang terjadi phlebitis sebanyak 26 $(92,9 \%)$ dan yang tidak terjadi phlebitis yaitu $1(14,3 \%)$ responden. Terjadinya phlebitis disebabkan karena pada pertama kali insersi terjadi kerusakan jaringan, apabila ada jaringan yang terluka atau terbuka akan memudahkan mikroorganisme masuk. Masuknya mikroorganisme tersebut maka tubuh akan merespon dan ditandai adanya proses inflamasi. Proses inflamasi yang merupakan reaksi tubuh terhadap luka dimulai setelah beberapa menit dan berlangsung selama 3 hari setelah cedera (Potter \& Perry, 2010).

Responden yang tidak mengalami phlebitis sekalipun telah diinsersi sebanyak $>2$ kali disebabkan karena beberapa faktor, diantaranya yaitu adanya lokasi pemasangan yang kurang tepat dan status gizi seseorang. Manurut La Rocca (2011) perkiraan lokasi pemasangan terapi infus menjadi faktor yang lebih penting dalam seleksi pembuluh, sehingga disarankan untuk memilih pembuluh darah yang panjang dan tidak bercabang. Untuk itu lokasi penusukan jarum infus mulai dari sejauh mungkin dan berpindah dalam arah proksiamal pada kedua tangn secara bergantian. Vena-vena yang digunakan untuk terapi intravena adaalah vena metacarpal atau area punggung tangan, vena sefalica dan basalica atau pergelangan tangan, hindari penggunaan pada daerah lipatan tangan dan siku, karena lipatan siku atau lengan mengakibatkan pelipatan kanula dalam pembuluh darah dan menimbulkan komplikasi terjadinya phlebitis. Selain itu, pasien dengan status gizi di bawah batas normal akan kekurangan energi dan berkaitan dengan 
kelemahan dalam fungsi fagosit, seksresi antibodi dan produksi sitokin. Selain itu, gizi yang berlebih juga dapat menurunkan imunitas (Siagian, 2010).

Phlebitis dapat terjadi akibat tidak adanya mekanisme untuk mempertahankan lokasi insersi maupun teknik insersi pada pertama kali. Hasil penelitian ini sesuai dengan hasil penelitian Pearson (2011) yang mengatakan bahwa insersi pada vena yang terpasang infus mempunyai resiko terjadi phlebitis. Kejadian phlebitis juga dapat terjadi akibat perawatan kateter intravena dengan tidak menggunakan kassa antibiotik yang steril. Sesuai dengan penelitian Asrin, Triyanto, \& Upoyo (2016) yang menemukan bahwa faktor-faktor yang mempengaruhi terjadinya phlebitis adalah jenis, ukuran dan bahan kateter, lama waktu pemasangan, pemilihan tempat insersi, jenis penutup tempat penusukan (dressing), teknik insersi/penusukan, sterilitas perawatan terapi intravena, cairan intravena, obat parenteral, dan frekuensi perawatan terapi intravena, sedangkan faktor paling dominan adalah lama pemasangan kateter.

Adanya bengkak, rasa nyeri dan merah pada area lokasi penusukan merupakan respon inflamasi yang menyebabkan ketidaknyamanan pada responden. Ketidaknyamanan tersebut membuat kondisi responden semakin buruk karena menambah penyakit yang dideritanya, sehingga perlu penanganan dari petugas kesehatan. Dalam hal ini sesuai dengan teori yang dikemukakan oleh Aryani, et al., (2009) bahwa kejadian phlebitis pada skala 2 memiliki tanda gejala nyeri, bengkak dan terdapat eritema di area penusukan.

\section{SIMPULAN}

Berdasarkan hasil penelitian tentang hubungan jumlah insersi dan rotasi infus dengan kejadian phlebitis pada pasien anak di RSUD Kota Kendari, maka kesimpulan yang dapat diambil adalah: Ada hubungan antara jumlah insersi dengan kejadian phlebitis pada pasien anak. Hal tersebut dibuktikan dengan hasil uji statistik fisher exact diperoleh nilai $\rho$ value $=0,000$, sehingga dapat disimpulkan bahwa secara statistik terdapat hubungan yang signifikan antara jumlah insersi dengan kejadian phlebitis pada pasien anak di Ruang Mawar RSUD Kota Kendari.

\section{DAFTAR PUSTAKA}

Arikunto, Suharsimi. (2012). Prosedur Penelitian Suatu Pendekatan Praktik. Jakarta: Rineka Cipta.

Aryati, H. A. (2012). Hubungan antara komunikasi terapeutik perawat dengan kepuasan pasien di Rumah Sakit Islam Kendal. Fikkes Jurnal Keperawatan , 2 (2), 36-41.

Asmuji. (2012). Manajemen Keperawatan: Konsep dan Aplikasi. Yogyakarta: Ar-Ruzz Media.

Asniati Mus. (2009). Gambaran Tingkat Kepuasan Pasien Terhadap Pelayanan Keperawatan Rumah Sakit Umum Daerah Kabupaten Sinjai. UIN.

Bhayangkara, N. (2013). Hubungan antara Komunikasi Terapeutik Perawat dengan Kepuasan Pasien Dinas POLRI.

Damaiyanti, M. (2010). Komunikasi Terapeutik dalam Praktik Keperawatan. Jakarta: EGC.

Depkes. (2009). Sistem Kesehatan Nasional. Jakarta.

Dwilaksono, A. (2012). Analisis Pengaruh Fasilitas, Kualitas Pelayanan Keperawatan Pelanggan terhadap Minat Mereferensikan. Jurnal Buletin Penelitian Sistem Kesehatan, 9 (4).

Effendy, O. U. (2010). Ilmu, Teori, dan FIlsafat Komunikasi. Bandung: PT. Remaja Rosdakarya.

Fajar, Marhaeni. (2009). Ilmu Komunikasi: Teori \& Praktik. Yogyakarta: Graha Ilmu.

Hanafi, I \& Sevia, D. (2012). Keterampilan Komunikasi Interpersonal Perawat 
Berpengaruh Peningkatan Kepuasan Pasien. Jurnal Stikes, 5 (2).

Hilda, N. A. (2017). Faktor-Faktor yang Mempengaruhi Penerapan Komunikasi Efektif oleh Perawat di Ruang Rawat Inap. Mahakam Nursing Journal , 2 (1), 9-17.

Husna, A. R. (2009). Analisa Hubungan Komunikasi Verbal dan Non Verbal Perawat Terhadap Tingkat Kepuasan Pasien. Graha Cendekia.

Keliat, A. B. (2014). Hubungan Terapeutik Perawat-Klien. Jakarta: EGC

Kemenkes. (2011). Pedoman Dan Standar Etik Penelitian Dan Pengembangan Kesehatan Nasional. Di unduh tanggal 12 Mei 2018.

Lestari, W. P. (2010). Analisa Faktor Penentu Tingkat Kepuasan Pasien di Rumah Sakit PKU Muhammadiyah Bantul. Jurnal UI .

Machfoedz, M. (2009). Komunikasi Keperawatan. Yogyakarta: Ganbika.

Mandala, D. A. (2011). Analisa Hubungan Komunikasi Verbal dan Non Verbal Perawat Terhadap Tingkat Kepuasan Pasien. Surabaya: Universitas Airlangga.

Notoatmodjo. (2012). Metodologi penelitian Kesehatan. Jakarta: PT.RinekaCipta.

Nurhasanah, Nunung. (2009). Ilmu Komunikasi dalam Konteks Keperawatan untuk Mahasiswa Keperawatan. Jakarta: TIM.

Nursalam. (2012). Manajemen Keperawatan: Aplikasi dalam Praktik Keperawatan Profesional Edisi 3. Jakarta: Salemba Medika.

Nursalam. (2014). Manajemen Keperawatan: Aplikasi dalam Praktik Keperawatan Profesional. Jakarta: Salemba Medika.
Pohan. (2010). Jaminan Mutu Layanan Kesehatan; Dasar-Dasar Pengertian dan Penerapan. Jakarta: EGC.

Sajidin, M. (2009). Aplikasi Komunikasi dalam Keperawatan. Jakarta: Salemba Medika.

Sugiyono. (2015). Metode Penelitian Pendidikan (Pendekatan Kuantitatif, Kualitatif, dan $R \& D)$. Bandung: Alfabeta.

Supranto. (2012). Pengukuran Tingkat Kepuasan Pelanggan untuk Meningkatkan Pangsa Pasar. Jakarta: Rineka Cipta.

Suryani. (2011). Komunikasi Terapeutik: Teori dan Praktik. Jakarta: EGC.

Tamsuri, A. (2010). Komunikasi dalam Keperawatan. Jakarta: EGC.

Tjiptono, F. (2009). Manajemen Pemasaran. Yogyakarta: Andi.

Wijaya, M. (2010). Efektivitas Komunikasi Pelayanan Sektor Publik Di Sumatera Utara. Medan: Fakultas Ilmu Sosial dan Ilmu Politik Jurusan Administrasi Negara Universitas Sumatera Utara.

Wijono. (2013). Manajemen Mutu Pelayanan Kesehatan. Surabaya: Airlangga.

Wulan, Kencana \& M. Hastuti. (2011). Pengantar Etika Keperawatan Panduan Lengkap Menjadi Perawat Profesional Berwawasan Etis. Jakarta: Prestasi Pustakakarya. 